\title{
A Simulation Model for Hybrid Power System Sources (HPSS)Photovoltaic/Wind/Battery/ Diesel connected with Grid
}

\author{
Ronak Ahmad Saeed, Ergun Erceleb
}

\begin{abstract}
This paper presents the model of the hybrid power system for different energy sources photovoltaic (PV), wind turbine based permanent magnet synchronous generator(PMSG), diesel generator, battery and grid which are connected together for providing power generation and to supply the electrical load. The purpose of this work is to investigate architecture of automatic power system sources to achieve a good performance of the individual sub models for the system and to choose the cheapest source that can supply the load demand at minimum cost and maximum availability while preserving the reliability of the system. The control strategy is adopted for studying this model and control management strategy is developed to operate the system (PV/wind/diesel/battery/grid) HPSS in most efficient way. Matlab /Simulink is utilized to simulate the overall system model for different power sources and for plotting the results.
\end{abstract}

Keywords - Grid connected hybrid power system, Simulation of HPSS, Solar-wind-diesel and battery modelling in Simulink.

\section{INTRODUCTION}

Due to raising the price of petroleum product's and advances in renewable energy technologies, hybrid renewable energy systems (HRES) are becoming popular in power systems for providing electricity in remote areas. A hybrid energy source consists of more than one renewable energy system which are applied with each other to excess power system efficiency as well as greater balance in energy supply.

The integration of two or more energy sources is known as hybrid power system. The fundamental point of preference hybrid energy system is the improvement of unwavering quality of the hybrid power system and money saving advantage of the system. Hybrid energy system provides a high level of energy safety through the mix of generation techniques and easily combine a power storage system. Renewable energy sources such as solar and wind are omnipresent and environmental friendly. The renewable energy sources are emerging options to achieve the energy demand [1].

The collecting of combined solar, wind, diesel and battery power systems into the grid can help in reducing the overall cost and improving reliability of renewable power generation to supply its load and their system becomes more economical to run since the weakness of one system can be complemented by the strength of the other one[2].

Ronak Ahmad Saeed, Ergun Ercelebi are at the Department of Electrical and Electronics Engineering Gaziantep University, Turkey
Combining the two sources or more is a best solution for rural electrification where the grid connection not fulfil electricity demand. Technology of hybrid energy system is economically applicable and an emerging energy option since it promises great deal of challenges and opportunities developed in developing countries[3].

Hybrid power system source has gained more significance by many researchers such as ASHARI and C. V. NAYAR developed a computer program for a typical dispatch strategy to determinate the optimum values of using the diesel generator to minimise the overall system costs [4].

M. Belhamel, D. Saheb-KoussaandM. Haddadi, developed optimal design of a hybrid system using a mathematical modelling and reported the outputs of the technical-economic optimization research of wind /photovoltaic/diesel hybrid with battery storage [5].

Alalwan, Sami Hamed, and Jonathan W. Kimball. in their study analyzed typical meteorological data through using the forever power method to optimize the size of hybrid micro sources for an islanded MG with minimum operational cost and to allow the designer to select the size of best fits of the targeted availability, environmental benefit, cost and reliability[6].

\section{MethodOLOGY}

The hybrid power system sources are modeled and simulated in Matlab and Simulink. The proposed hybrid power generation system to produce electricity and supply the load with considering and studying three cases of loads. The system consists of the photovoltaic (PV) with the wind turbine based permanent magnet synchronous generator (PMSG), the battery. Moreover the system contain the diesel generator and grid to meet the load demand in case of the power sources of (solar and wind) are not sufficient to the load demand. For case study a solar PV module of $90 \mathrm{Kw}$ along with a wind power system of $10 \mathrm{Kw}$ is modeled in Simulink.

Solar and wind power have the highest priority as they are cheapest power sources. If the load is more than the capacity of solar and wind then rest of the demand is meet by grid supply. In case if grid is not available diesel generator as a backup power system, it begins to work as emergency power-supply to feed the load demand in this case, diesel works and satisfies the deficit power [7]. 


\section{HYBRID SYSTEM MODELING}

In this research modeling of the hybrid system is investigated as shown in Fig.1 which consists of the configuration renewable energy (photovoltaic-wind turbine)battery-diesel-connected with the grid as power generation and auto controller, converter (inverter, rectifier) with additional/auxiliary components which is helpful for full time functioning of the hybrid system. The performance of the systems can be predicted, firstly individual components should be modeled and then their combination can be evaluated to meet the demand reliability. If the power output prediction from these individual components is accurate enough, the resultant combination will deliver power at the least cost.

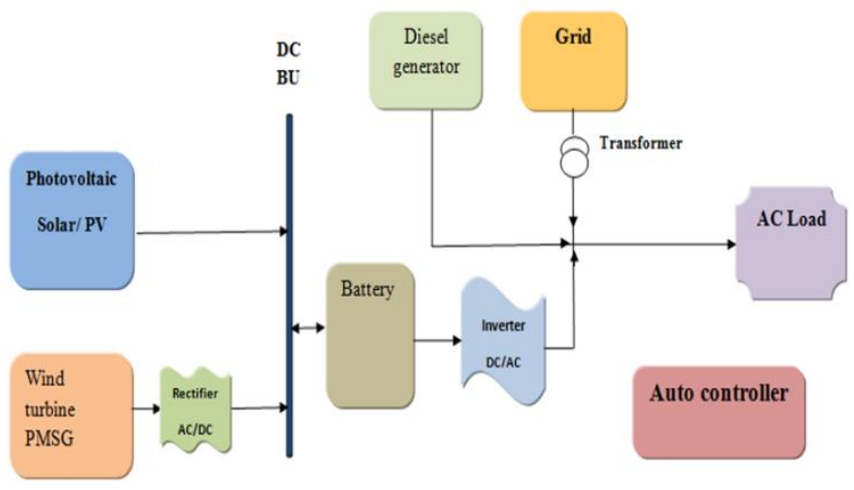

Fig.1 Schematic of proposed hybrid power system sources HPSS

\section{A. Modelling of Solar PV System}

Photovoltaic energy system is a process of generating electrical power by converting the power from sun light into D.C electricity using semiconductors that show the photovoltaic effect. Photovoltaic power generation solar panels, which includes a number of cells containing the semiconducting material. Main part of the PV array is a photovoltaic cell, which is just a simple $\mathrm{p} n$ junction device.Current is developed when solar irradiation strikes the solar cell. The typical model of solar cell is represented by an equivalent circuit shown in Fig.2.

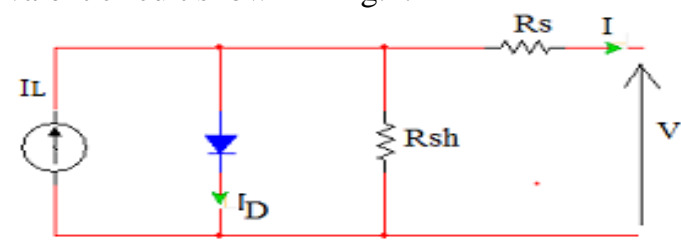

Fig.2 Equivalent electrical circuit of solar cell

Where IL represents the current source of the photocurrent cell. Rs and Rsh are the series and shunt resistances radical of the solar cell, Rsh is very large in value where Rs is very small, hence it can be ignored to simplify the analysis [8]. The net current of the cell is the represented by the equation (1):

$I=I L-I s\left[\exp \frac{q(v+I R s)}{N K T}-1\right]-\frac{(v+I R s)}{R s h}$
Where (Is) is the diode saturation current, $\mathrm{q}$ is the electron charge, $\mathrm{V}$ is the terminal voltage of the cell, $\mathrm{N}$ is the diode ideality factor, $\mathrm{K}$ is the Boltzmann constant, $\mathrm{T}$ is the cell temperature.

FIG. 3 shows a PV module consists of 40 parallel strings and each of them consists of 10 series connected module of 1Soltech 1STH-215-P solar panel provided by 1 Soltech and in each module there are 60 cells. The solar photovoltaic array is being operated at constant irradiance of $1000 \mathrm{~W} / \mathrm{m} 2$ and solar photovoltaic panels are tested at $25^{\circ} \mathrm{c}$.

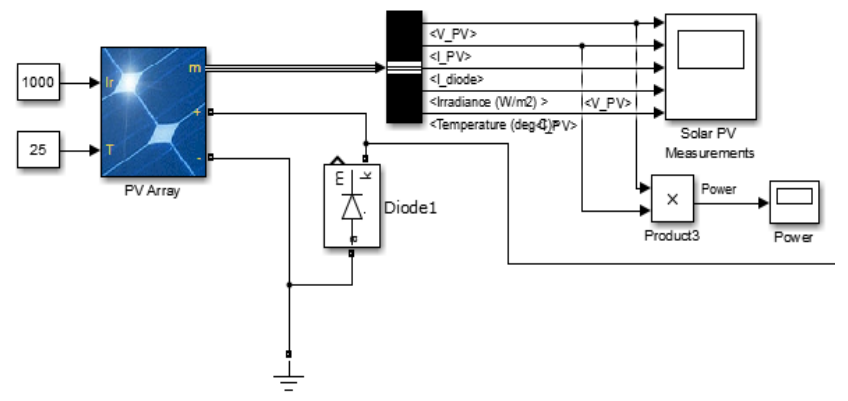

Fig. 3 Solar PV model in Simulink

FIG.4 depicts the maximum power operating point at different irradiance values. The effects of different irradiation level on $\mathrm{I}-\mathrm{V}$ and $\mathrm{P}-\mathrm{V}$ characteristics are presented respectively. As can be seen in Fig below the variation of irradiation level affects widely on the voltage generated and current in PV module.
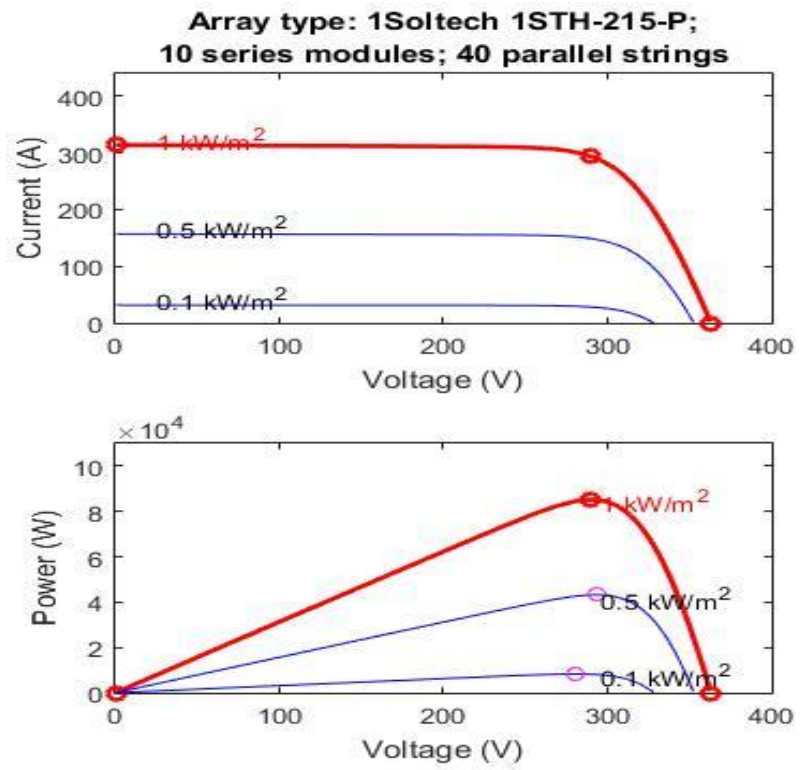

Fig. 4 Maximum power produced by solar PV array

The solar photovoltaic array is simulated at different temperatures to show the effect of temperature variation on the $\mathrm{P}-\mathrm{V}$ and I-V characteristics as plotted in the Fig. 5 as a temperature increases power generated decreases, because on increment of temperature voltage decreases. So the percentage of temperature coefficient illustrates that the change in efficiency as it goes up or down by a degree [9]. 

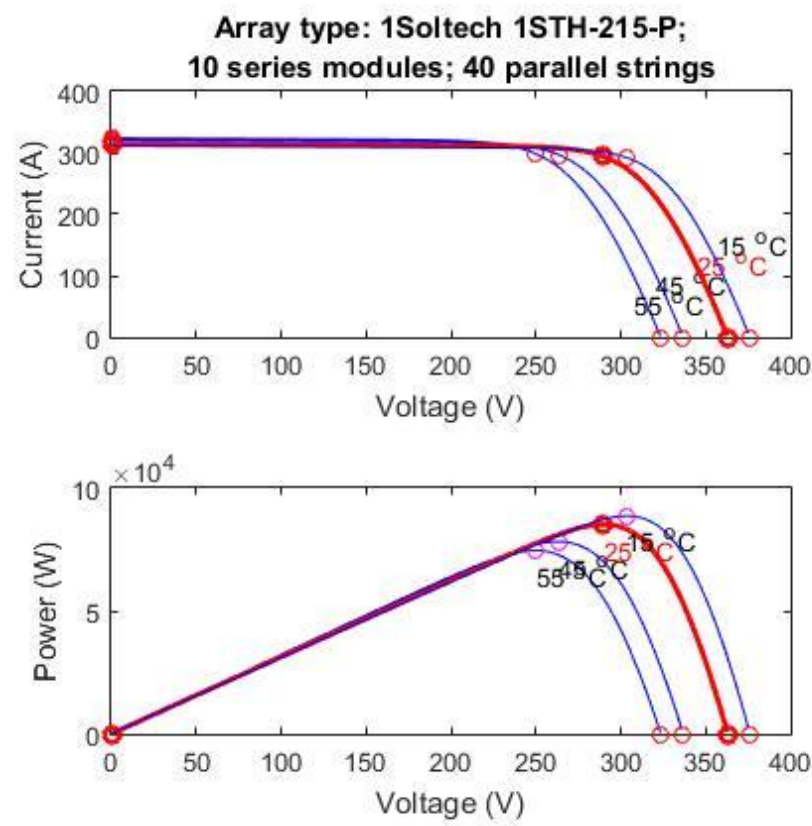

Fig. 5 Solar PV module characteristics at various temperatures

\section{B.Modelling of Wind Power Generation System}

Wind is the movement of air mass and it has kinetic energy. This kinetic energy of the wind can be converted into mechanical energy using a wind turbine with rotor blades. Then through using a generator the mechanical energy is converted to electrical energy.

The permanent magnet synchronous generator (PMSG) is used to convert the wind power into electrical power. Comparing all the type of generators that are used in wind turbines the PMSG's have the highest advantages because of during normal operation they are more stable, secure and it provides higher efficiency in lower speed applications essentially the wind's kinetic energy in the rotor which is mechanically coupled to generators comes from wind turbine [10]. The fundamental equations can be given as:

$$
\mathrm{P}_{\mathrm{WIND}}=0.5 \mathrm{~A} \rho \mathrm{V}^{3}
$$

Where, $\rho$ is the air density, A is the swept area of rotor and $\mathrm{v}$ is the wind speed. From the total wind energy only a part can be extracted or used. The power coefficient $\mathrm{Cp}$ is a part of available energy in wind. The maximum value of theoretical coefficient is 0.59 which is called the Betz limit.

$$
\mathrm{P}_{\text {TURBINE }}=0.5 \mathrm{C}_{\mathrm{P}} \mathrm{AV}^{3}
$$

The coefficient of power is a function of the tip-speed ratio $\lambda$

$$
\lambda=\mathrm{r} \Omega / \mathrm{V}
$$

Where $r$ is the radius of the rotor and $\Omega$ is indicate the speed of angular rotor [11].

A 3 phase round rotor type permanent magnet synchronous generator is used to generate wind power [12]. An auto pitch angle controller is deciding the pitch angle of wind turbine blades. Base wind speed is considered as 12 $\mathrm{m} / \mathrm{s}$.
The model of wind system as shown in Fig.6 is based on the steady-state power characteristics of the turbine. The stiffness of the drive train is infinite and the friction factor and the inertia of the turbine must be combined with those of the generator coupled to the turbine.
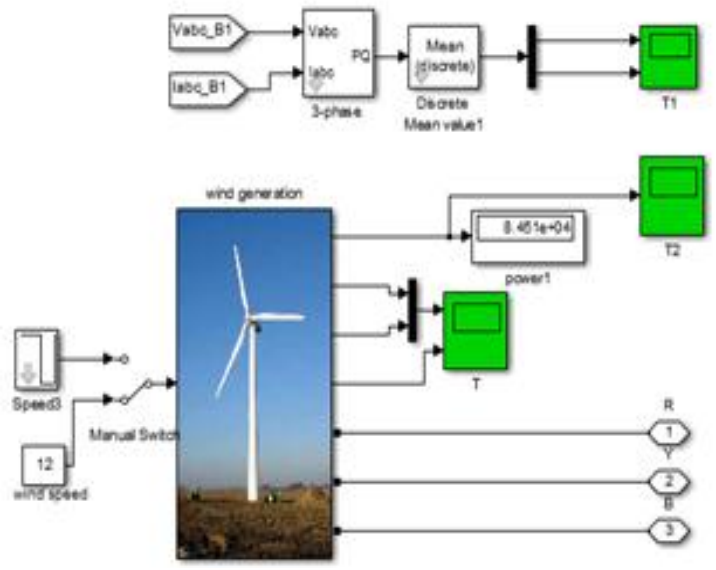

Fig.6 Wind power generation model in Simulink/Matlab[13]

FIG.7 presents wind power characteristics model at different wind speed. As can be observed that the output power of the turbine is increased with increasing the speed of the wind. Maximum power could be extracted when the wind turbine speed can keep track of the wind speed changes, when speed of wind is $12 \mathrm{~m} / \mathrm{s}$, maximum power is obtained the turbine speed is at 1 per unit.

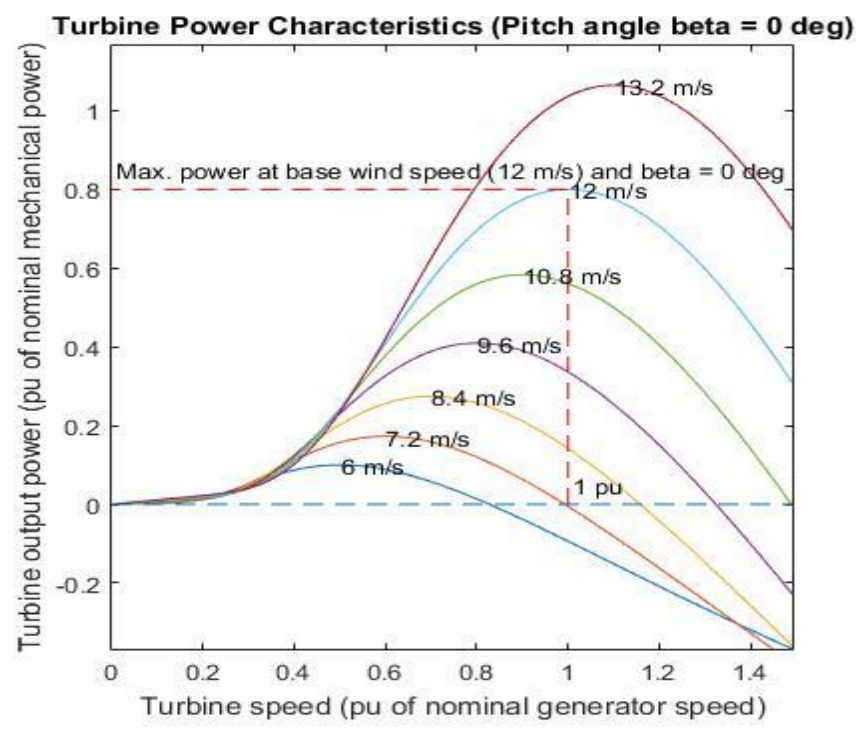

Fig.7 Wind power Characteristics model in Simulink[13]

\section{Modelling of Battery}

Nickel-Metal-Hydride battery of capacity of 10,000 Ah is being used to store the power generated by renewable sources as solar PV and wind generator [14].The stored power in battery further being used to meed the load demands use of ultra-capacitor can improve the overall system efficiency and reliability. The DC power is converting into AC power through 
an inverter before reaching the load. Battery system model and characteristics are shown in Fig. 8 and Fig. 9.

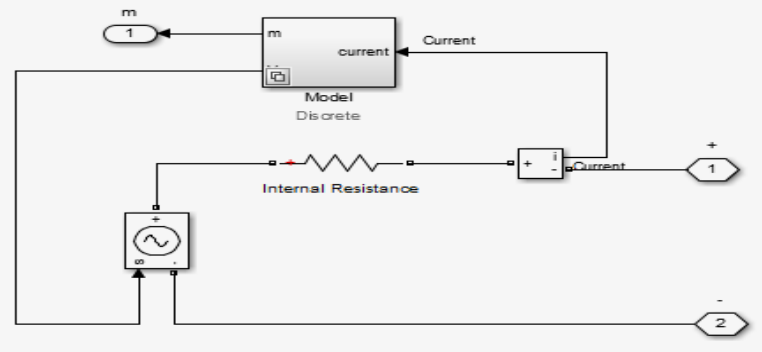

Fig. 8 Battery system Model in Simulink/MATLAB [13]
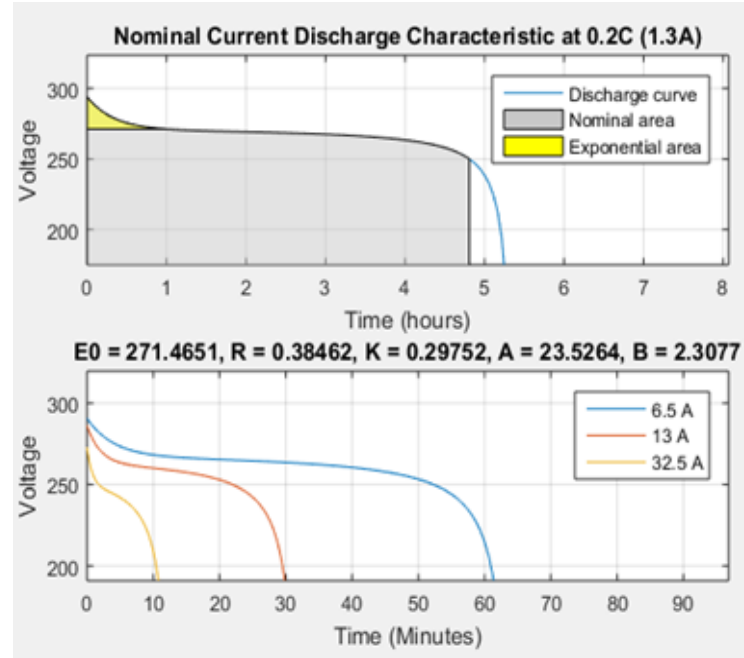

Fig.9 Battery discharge characteristics plotted against time [13]

\section{E. Modelling of Diesel Generator}

The set of diesel generator changes fuel energy (diesel or bio-diesel) into mechanical energy using of an internal burning engine, and then into electric energy via the working of an electric machine as generator. A diesel power system is considered for emergency situations as depicts in Fig.10 asynchronous machine of 3.123 MVA connected with diesel engine governor which is generating 3 phase AC power. An excitation system is providing the DC voltage to the field winding of synchronous machine [15]

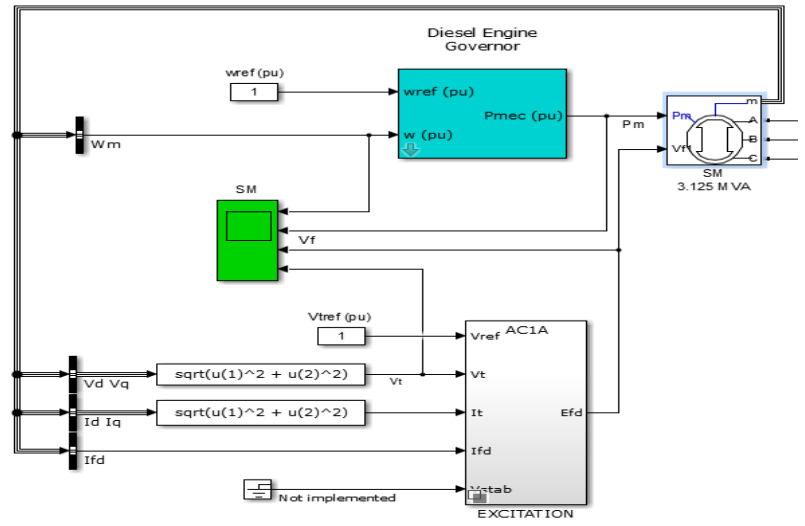

Fig.10 Diesel generation Simulink model[13]

\section{F. Modelling of Inverter}

FIG. 11 shows the model of IGBT inverter controlled by PWM which is used to convert the DC power into AC power. A voltage regulator along with a $\mathrm{LC}$ filter is being used as the input to PWM generator. DC/AC inverter acts as an interface between the power sources and the loads to provide the required power to the load by regulating the $\mathrm{AC}$ output voltage [17].

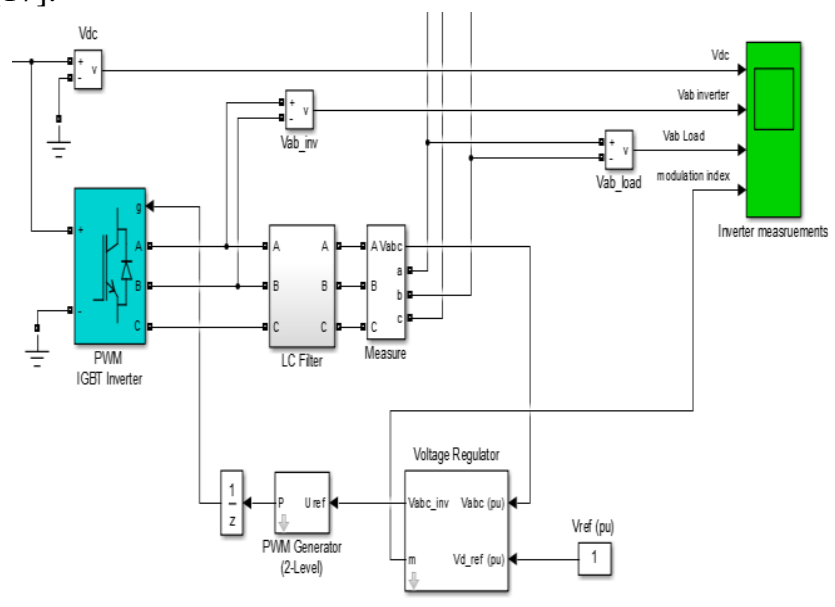

Fig.11 Inverter model

\section{Control Strategy}

A simple load based control strategy shown in Fig.12 is adopted for studying this model. Based on the switching the loads, power supply sources are automated.

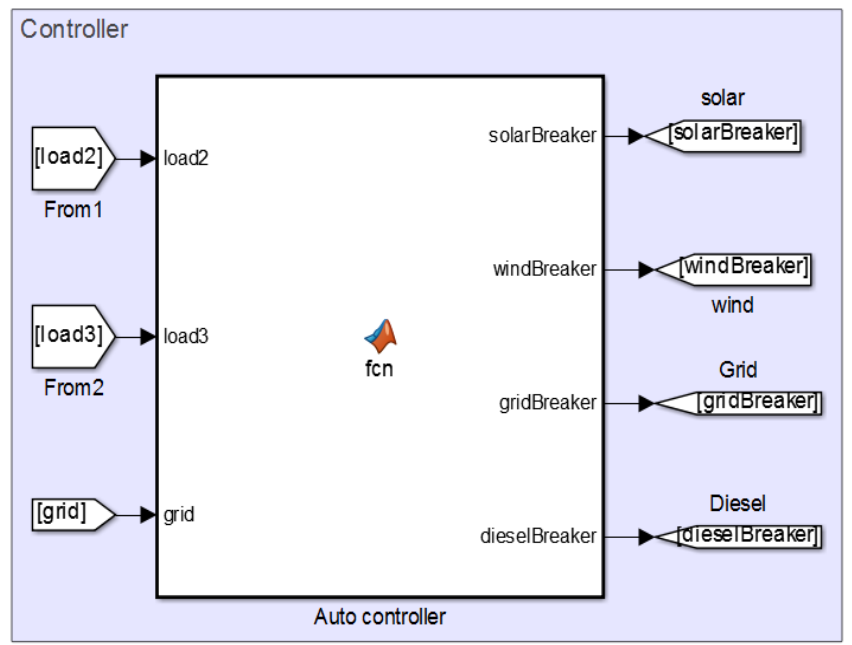

Fig.12 Block control strategy

The model has the flexibility to make grid supply on or off. Out of three loads, load 2 and load 3 can be switched on or off manually. Based on the load switching selection, the control algorithm will decide the power sources to be used to meet the load demand. It is noted that, power produced by solar PV and wind turbine are considered to be available all the time. The excess power is being used to charge the battery [16]. Fig .13 represents user operation and power sources status panel of the model. 


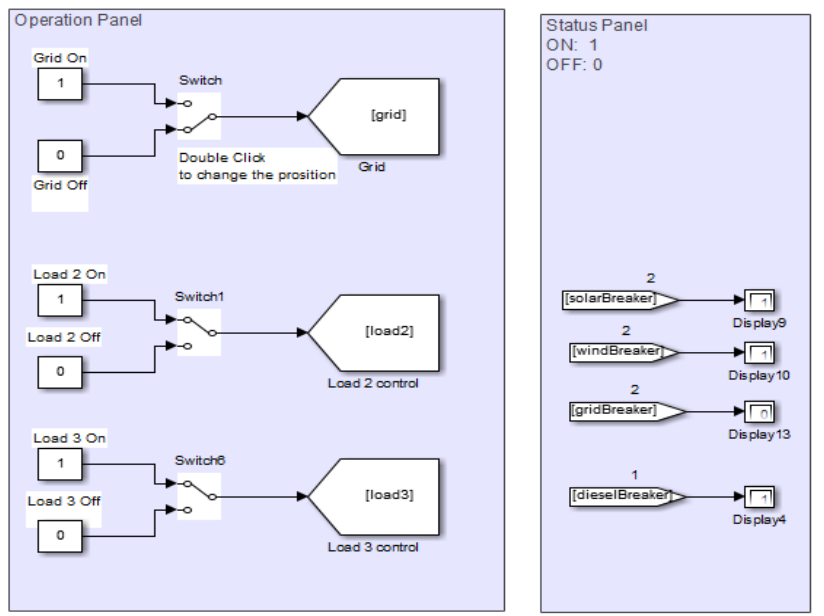

Fig. 13 User operation and power sources status panel.

\section{RESUlT AND DISCUSSIONS}

In this section, 3 cases of phase load variation are studied and considered according to usage of sources then the control algorithm will determine the power sources that need to be applied to meet the load demand. The simulation results of the three cases are obtained from the Matlab/Simulink and explained in the following cases.

\section{A. Case Study One}

In first case study only one load as $(50 \mathrm{Kw})$ is considered, solar and wind are connected to the system. The generated power by solar is sufficient to supply the load demand and the power produced by wind generation is being used in charging the battery.

\section{B. Case Study Two}

In second case study a $10 \mathrm{Kw}$ local $\mathrm{AC}$ load is applied to the system with the load of $(50 \mathrm{Kw})$. This load is supplied by both the sourcesof solar and wind turbine.

\section{Case Study Three}

In a third case three loads of $(50 \mathrm{Kw}, 10 \mathrm{Kw}$ and $3.1 \mathrm{MW})$ are connected to the system. In this case solar and wind generation are not sufficient to supply the load demand, so the system need to one more power source as a gird or diesel. The diesel is more costly compared to the grid. Control Algorithm checks the status that the grid supply is available or not. If the grid is available sufficient to supply the power to the load, in this case three systems (Solar, Wind and Grid) have to run together and offer a stable system. If the grid supply is not available, then diesel power system is being used as the emergency source with (Solar, Wind ) and sufficient to provide the required power to the load.

Simulation result of wind power generation is shown in Fig.14 the speed of the wind starts to increase then the wind turbine begins to rotate and the PMSG begins to generate electrical power, with increasing the speed of the wind the generated electrical power are gradually increased, the wind speed reaches and stops increasing, soon after that the system comes to the steady state. In the steady state the wind speed keeps increasing and exceeds the rated value.

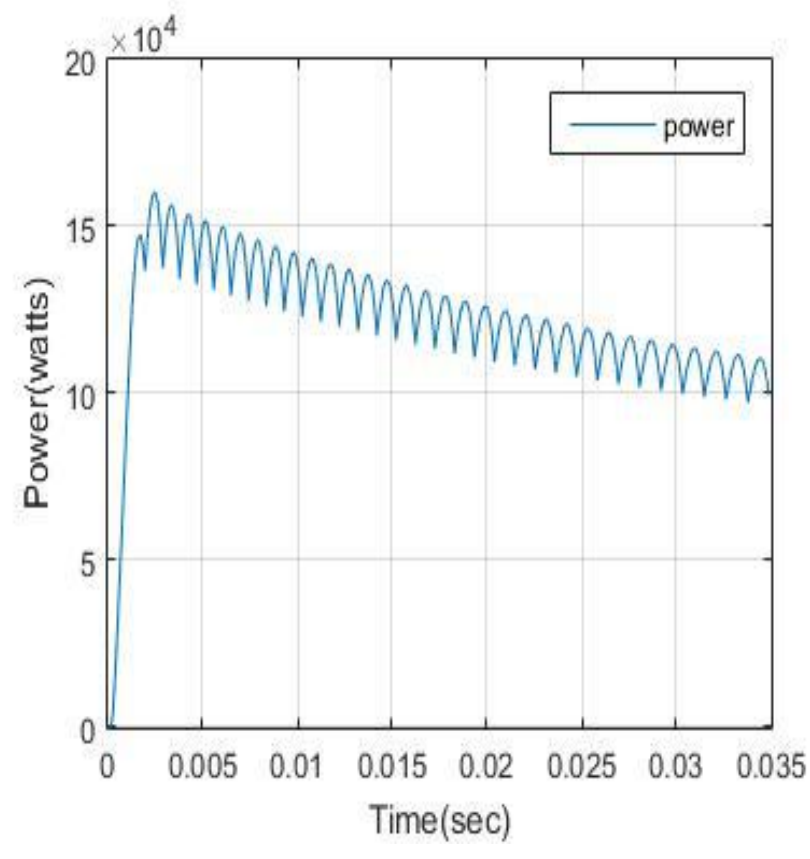

Fig. 14 Wind power generation results.

FIG. 15 shows the power generated by solar, the model is tested at $25^{\circ} \mathrm{C}$ degree, irradiance is fixed in of $1000 \mathrm{~W} / \mathrm{m} 2$. In this simulation, The average power generated by solar PV is approximately $90 \mathrm{~kW}$.

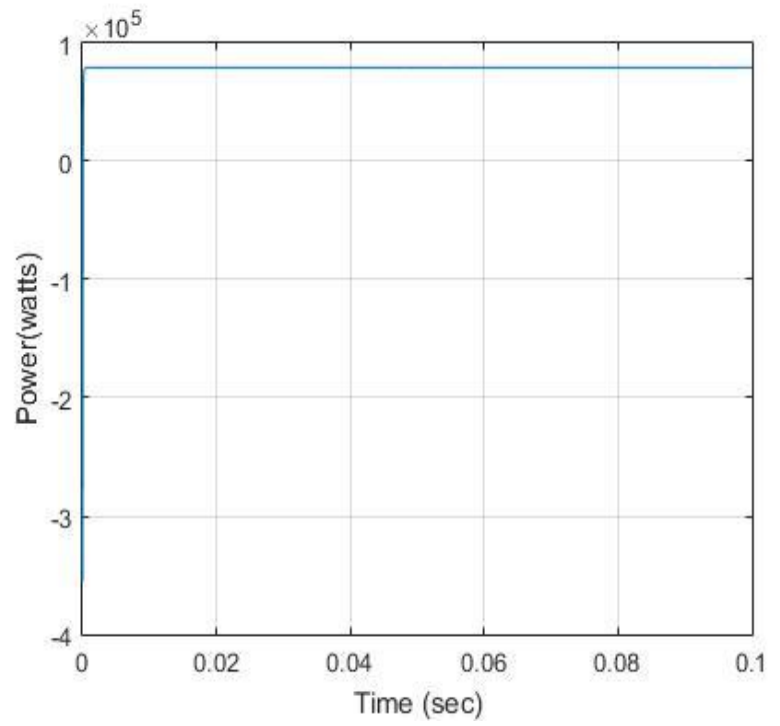

Fig.15 Solar power produced (in watts).

Fig.16 Shows surplus power is being used in charging the battery system and the state of charge (SOC) of battery is increasing which signifies that battery is getting charged. This can be confirmed by the current value which is negative. At discharging, the battery starts to supply constant voltage and state of charge is decreasing and also the current become positive during discharging which is supplying the power to the load. 


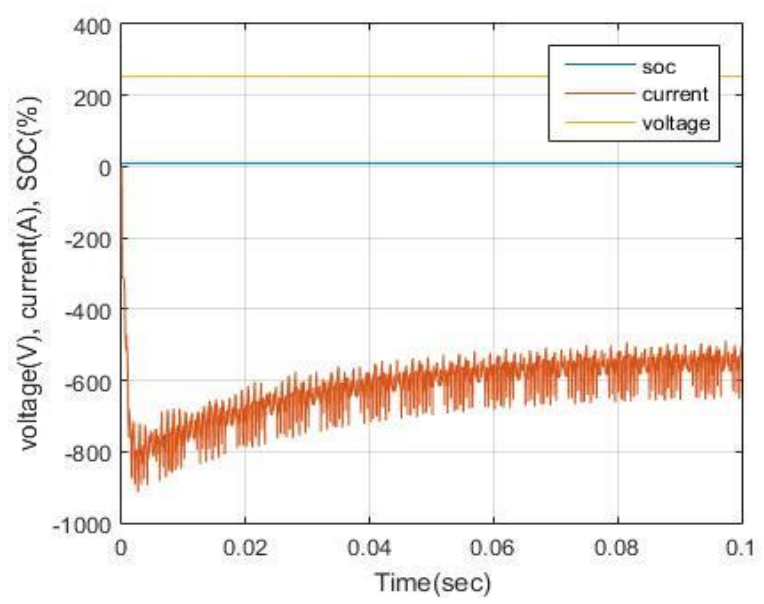

Fig.16 Battery characteristics (during charging)

The Inverter characteristics are shown in Fig.17 (Vdc bus ,inverter output without Filter, inverter output with Lc Filter).

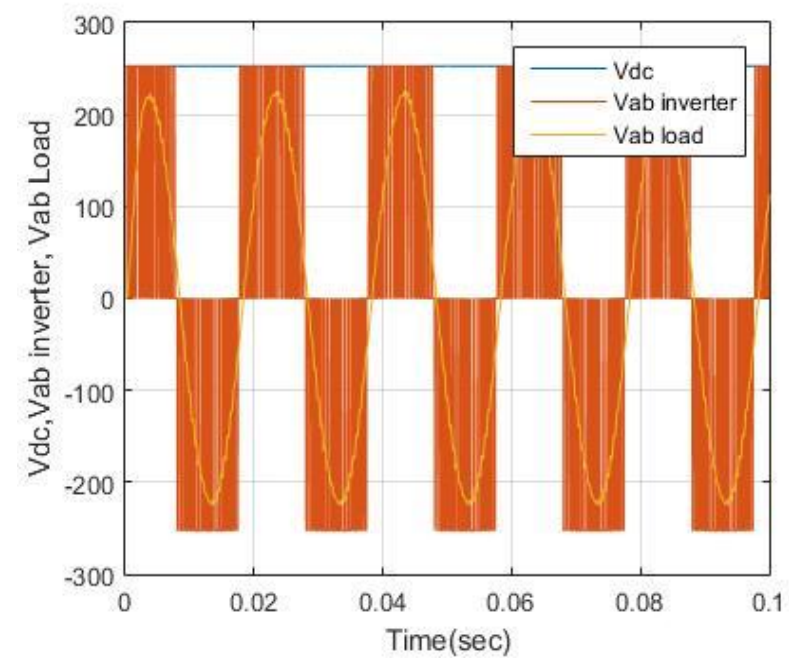

Fig. 17 Inverter characteristics

FIG.18 is represented output current (Ia, Ib, Ic) and voltage $(\mathrm{Va}, \mathrm{Vb}, \mathrm{Vc})$ of diesel generator.

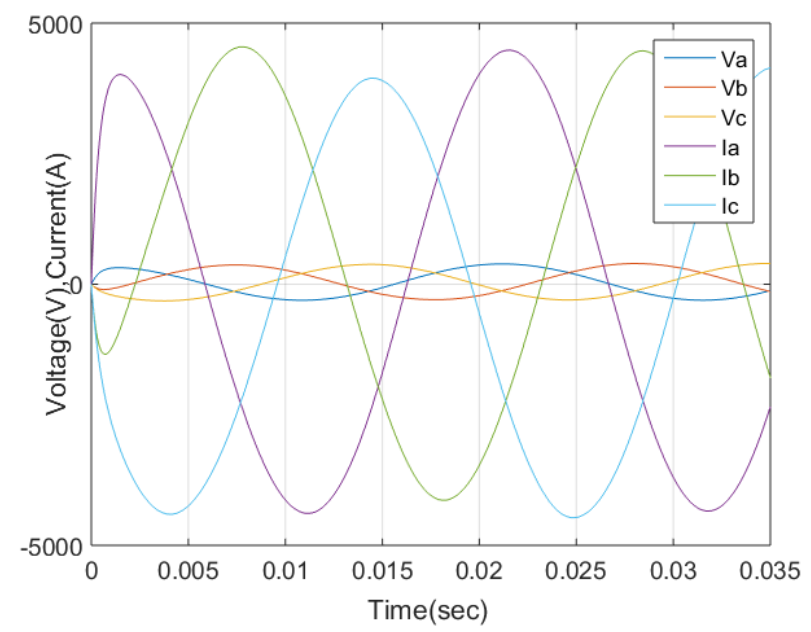

Fig.18 Diesel generation results

\section{CONCLUSION}

A proposed model of hybrid power system sources (HPSS) designed and simulated using MATLAB/Simulink. This project investigated the work by connection different power generation system which consist of renewable energy (photovoltaic (PV), wind turbine based permanent magnet synchronous generator (PMSG)), Battery, Diesel generation set power system and Grid which are generating energy for an AC load and with a continuous electric power production to supply the load. The control strategy is utilized for studying this model HPSS to choose the cheapest sources and minim cost to meet the load demand. A power management developed to improve the reliability of hybrid system operation. All the results obtained from the simulation are demonstrated. Also the paper shows an insight of the various entry and exit conditions of each zone or (quantity of the loads) of operation thereby it can efficiently switch (by auto control) between different type generating units to meet the demand efficiently.

\section{REFERENCES}

[1] Khare, Vikas, SavitaNema, and PrashantBaredar. "Solar-wind hybrid renewable energy system: A review." Renewable and Sustainable Energy Reviews 58 (2016): 23-33 http://dx.doi.org/10.1016/j.rser.2015.12.223

[2] Badwawi, Rashid Al, Mohammad Abusara, and Tapas Mallick. "A review of hybrid solar PV and wind energy system." Smart Science 3.3 (2015): 127-138.

http://dx.doi.org/10.1080/23080477.2015.11665647

[3] Pawar, Shekhar K., et al. "Modeling and simulation of hybrid solar-wind-grid power generation system for electrification." Advances in Engineering and Technology (ICAET), 2014 International Conference on. IEEE, 2014 http://dx.doi.org/10.1109/icaet.2014.7105291

[4] Ashari, Mochamad, and C. V. Nayar. "An optimum dispatch strategy using set points for a photovoltaic (PV)-diesel-battery hybrid power system." Solar Energy 66.1 (1999): 1-9. http://dx.doi.org/10.1016/S0038-092X(99)00016-X

[5] Saheb-Koussa, D., M. Haddadi, and M. Belhamel. "Economic and technical study of a hybrid system (wind-photovoltaic-diesel) for rural electrification in Algeria." Applied Energy 86.7 (2009): 1024-1030. http://dx.doi.org/10.1016/j.apenergy.2008.10.015

[6] Alalwan, Sami Hamed, and Jonathan W. Kimball. "Optimal Sizing of a Wind/Solar/Battery Hybrid Microgrid System Using the Forever Power Method." Green Technologies Conference (GreenTech), 2015 Seventh Annual IEEE. IEEE, 2015. http://dx.doi.org/10.1109/greentech.2015.21

[7] Maleki, Akbar, and AlirezaAskarzadeh. "Optimal sizing of a $\mathrm{PV} /$ wind/diesel system with battery storage for electrification to an off-grid remote region: A case study of Rafsanjan, Iran." Sustainable Energy Technologies and Assessments 7 (2014): 147-153. http://dx.doi.org/10.1016/j.seta.2014.04.005

[8] N. Pandiarajan and RanganathMuthu," Mathematical Modeling of Photovoltaic Module with Simulink", International Conference on Electrical Energy Systems.

[9] X. Cai ; S. Zeng ; X. Li ; J. Zhang," Effect of light intensity and temperature on the performance of GaN-based p-i-n solar cells", Electrical and Control Engineering (ICECE), 2011 International Conference, pp 1535 - 1537, Sep. 2011. http://dx.doi.org/10.1109/iceceng.2011.6058463

[10] Chowdhury, MujaddidMorshed. Modelling and control of direct drive variable speed wind turbine with Interior Permanent Magnet Synchronous Generator. Diss. University of Tasmania, 2014.

[11] L Dodson, K Busawon and M Jovanovic," Estimation of the power coeccient in a wind conversion system", 44th IEEE Conference on Decision and Control, and the European Control Conference, pp 12-15, Dec. 2015.

[12] Krause, P.C., O. Wasynczuk, and S.D. Sudhoff. Analysis of Electric Machinery and Drive Systems. IEEE Press, 2002. 
http://dx.doi.org/10.1109/9780470544167

[13] Matlab®/ Simulink $®$, SimPowerSystems, Examples, 2015b

[14] Tremblay, O., Dessaint, L.-A. "Experimental Validation of a Battery Dynamic Model for EV Applications." World Electric Vehicle Journal. Vol. 3 - ISSN 2032-6653 - (C) 2009 AVERE, EVS24 Stavanger, Norway, May 13 - 16, 2009

[15] TiberiuTudorache, Cristian Roman, "The Numerical Modeling of Transient Regimes of Diesel Generator Sets", ActaPolytechnicaHungarica. Vol. 7, No. 2, 2010..

[16] T. M. Undeland ; O. Ulleberg; P. J. S. Vie, "Optimal load sharing strategy in a hybrid power system based on PV/Fuel Cell/ Battery/Supercapacitor", pp 141 - 146, June 2009

[17] Mohan, N., T.M. Undeland, and W.P. Robbins, Power Electronics: Converters, Applications, and Design, John Wiley \& Sons, Inc., New York, 1995.

Ronak Ahmad Saeed. Received B.Sc. degrees in Electrical Engineering from Electrical Engineering in Salahaddin University-Erbil, Iraq. Now she is master student in Electric and Electronic Engineering Department Gaziantep University, Turkey. She worked in Technology Institute, Ministry of Higher Education and Scientific Research of Erbil, Iraq.She is a member of Engineers Union in Erbil-Iraq.

Dr.Ergun Erceleb Received B.S. degree in Electrical and Electronics Engineering from METU, Gaziantep, Turkey in 1990 and M.S. and Ph.D. degrees in Electrical and Electronics Engineering from University of Gaziantep in 1992 and 1999 respectively. He was the head of Computer Engineering, University of Gaziantep between 2003 and 2004. He is presently Professor and head of dept of electrical electronics department, University of Gaziantep. His research interests include speech processing, image processing, adaptive filters, neural networks, statistical signal processingwavelet. 